\title{
Factors associated with the frequency of medical consultations by older adults: a national study
}

\author{
Fatores associados à frequência de consultas médicas por idosos: \\ estudo de base nacional \\ Factores asociados con la asistencia a consultas médicas por \\ personas mayores: estudio de base nacional
}

How to cite this article:

Meier JG, Cabral LPA, Zanesco C, Grden CRB, Fadel CB, Bordin D. Factors associated with the frequency of medical consultations by older adults: a national study. Rev Esc Enferm USP. 2020;54:e03544. DOI: http://dx.doi.org/10.1590/S1980-220X2018048103544

\section{Joyce Grabher Meier ${ }^{1}$ \\ Luciane Patrícia Andreani Cabral ${ }^{1}$ \\ Camila Zanesco ${ }^{2}$ \\ Clóris Regina Blanski Grden ${ }^{3}$ \\ Cristina Berger Fadel ${ }^{4}$ \\ Danielle Bordin ${ }^{3}$}

${ }^{1}$ Hospital Universitário Regional dos Campos Gerais, Ponta Grossa, PR, Brazil.

${ }^{2}$ Universidade Estadual de Ponta Grossa, Setor de Ciências Biológicas e da Saúde, Ponta Grossa, PR, Brazil.

${ }^{3}$ Universidade Estadual de Ponta Grossa, Departamento de Enfermagem e Saúde Pública, Ponta Grossa, PR, Brazil.

${ }^{4}$ Universidade Estadual de Ponta Grossa, Departamento de Odontologia, Ponta Grossa, PR, Brazil.

\begin{abstract}
Objective: To analyze factors associated with the high frequency of medical consultations (five or more consultations) among older adult participants of the National Health Survey - 2013. Method: A quantitative cross-sectional study conducted with data from individuals aged 60 years and over $(n=19,503)$. The outcome variable came from the question: 'How many times have you consulted the doctor in the last 12 months? Fiftyseven (57) independent variables were listed. The Waikato Environment for Knowledge Analysis software program was used in the analysis. The data set was balanced and the dimensionality reduction test was performed. The variables which were strongly related to the dependent variable were analyzed using logistic regression. Results: The independent variables listed were strongly related to the outcome variables: female gender, negative self-perception of health condition, inability to perform usual activities for health reasons, diagnosis of chronic disease, seeking health services for health-related care, and hospitalization. Conclusion: The results reflect the relevance of expanding and qualifying services through effective prevention, protection and health promotion actions.
\end{abstract}

\section{DESCRIPTORS}

Aged; Health of the Elderly; Indicators of Health Services; Interdisciplinary Placement; Health Services; Geriatric Nursing.

\author{
Corresponding author: \\ Danielle Bordin \\ Departamento de Enfermagem e Saúde Pública, \\ Universidade Estadual de Ponta Grossa. \\ Av. Carlos Cavalcante 4748 \\ Bloco $\mathrm{M}$, Campus de Uvaranas \\ CEP 84030-000 - Ponta Grossa, PR, Brazil. \\ daniellebordin@hotmail.com
}

Received: 11/01/2018

Approved: 04/11/2019 


\section{INTRODUCTION}

The change in the age structure in society due to reduced birth rates and increased life expectancy is not always accompanied by changes which ensure decent conditions during aging $^{(1-6)}$. The added amount of years lived has contributed to a higher incidence of diseases ${ }^{(7)}$, especially chronic non-communicable diseases, which contribute to a worsening in functional disability and compromise the quality of life of older adults ${ }^{(6,8)}$.

The indicated changes have a direct impact on the increased demand for healthcare ${ }^{(2,5)}$, regardless of the modality to be taken advantage of and its purpose, with consultations with a medical professional being one of the most recurrent alternatives ${ }^{(4,9)}$. It is well known that medical appointments are a promising instrument for early diagnosis, preventive action, treatment and necessary guidance. However, excessive use (five or more consultations) of this type of care may reflect the low resolution of health services, with negative repercussions in terms of economic and service levels, personal and collective contexts ${ }^{(2)}$.

In view of the above and the lack of studies related to the theme, it is necessary to know the factors which increase the use of medical consultations by Brazilian older adults, with a view to make adjustments in planning health actions which reduce unnecessary use of services, and provide value for quality and resoluteness with an emphasis on actions aimed at health promotion and prevention. Thus, in taking advantage of the significant position occupied by population-based surveys for assertive health decision-making, the objective of the present study was to learn the factors associated with the high frequency of medical consultations among Brazilian older adults participating in the current National Health Survey of 2013 (PNS (Pesquisa Nacional de Saúde) - 2013), thereby analyzing broad socioeconomic and health conditions.

\section{METHOD}

\section{StUdDY DESIGN}

This is a cross-sectional quantitative study with secondary data from a population-based survey (PNS - 2013), proposed by the Ministry of Health and conducted by the Brazilian Institute of Geography and Statistics (IBGE Instituto Brasileiro de Geografia e Estatística) ${ }^{(10)}$.

\section{Population}

The study is household-based and the sampling plan implemented a probabilistic three-stage cluster sampling, with the census tract set being the primary sampling units; the households being the secondary units, and the selected older residents as the tertiary units ${ }^{(10)}$.

The sample size was defined considering the desired level of precision for the estimates of some indicators of interest, resulting in information from 205,546 individuals residing in 60,202 investigated households ${ }^{(10)}$. For the present study we considered the information which came from older adults $(\mathrm{n}=23,815)$. Details on the sampling and weighting process are available in the PNS-2013 report $^{(10-11)}$.

\section{Data collection}

Data were collected by previously trained researchers. The information was obtained through individual interviews and stored on handheld computers. The participants were individuals over 18 years old. The interview was directed by three forms: the household, referring to the characteristics of the household; relating to all residents of the household; and the individual, answered by a randomly selected resident of the household who was 18 years of age or older ${ }^{(10)}$. We exclusively considered data from individuals over 60 years old from the last two forms in this study. Data from the PNS-2013 are publicly and freely available on the IBGE website.

\section{Data ANALYSIS AND PROCESSING}

The outcome variable 'Frequency of doctor visits in the last 12 months' results from the question: How many times have you consulted the doctor in the last 12 months? with numerical values as answers. Responses were grouped into up to 04 consultations and 05 or more medical consultations for the purpose of analysis in the present study. The presented categorization was adopted following the document "Parameters for programming basic health actions" of the Ministry of Health, which demands 3 annual consultations in primary care and 1 consultation at specialized level ${ }^{(12)}$.

In this categorization process it was found that 4,312 (18\%) did not answer the guiding question of the dependent variable, which were excluded from the sample. Thus, the final sample totaled 19,503 older adults.

In the pre-exploration phase, 57 variables of interest were listed to compose the independent variables, being related to: sociodemographic characteristics; limitations and illness; difficulties in performing basic and instrumental activities of daily living; use of health services; hospitalizations and medical emergencies; and life habits (Chart 1). All variables underwent processing, numerical variables were transformed into categorical variables, some variables were recategorized, and others dichotomized as recommended in the literature.

The subsequent step comprised balancing the data set in order to equalize the categories of the dependent variable benefiting the analysis procedure. For this step, the list of available balancing algorithms was tested, and the Resample algorithm was chosen due to its efficiency and compatibility with the study. Resample is a data preprocessing tool included in the data mining software program entitled Waikato Environment for Knowledge Analysis (WEKA) ${ }^{(13)}$. Next, the dimensionality reduction test was performed through the attribute selection method using the filter approach available in WEKA, using the Correlation-based Feature Selection (CFS) algorithm ${ }^{(14)}$, using the 10 -Fold Cross-validation method. 
Chart 1 - Description of the independent variables used in the study - PNS, Brazil, 2013.

\begin{tabular}{|c|c|}
\hline \multicolumn{2}{|c|}{ Sociodemographic characteristics } \\
\hline Gender & Civil status \\
\hline Age & Literacy \\
\hline Skin color/race & Education level \\
\hline Living with a partner & Income \\
\hline \multicolumn{2}{|c|}{ Physical limitations } \\
\hline Self-perception of health condition & Bedridden \\
\hline $\begin{array}{l}\text { The presence of chronic illness, physical or mental, somewhat limits } \\
\text { your usual activities }\end{array}$ & Number of days bedridden \\
\hline Has failed to perform any of their usual activities for health reasons & Movement difficulty \\
\hline Number of days no longer performing their usual activities for health reasons & Vision difficulty \\
\hline \multicolumn{2}{|c|}{ Difficulties Performing Basic Activities of Daily Living } \\
\hline $\begin{array}{l}\text { Difficulty eating alone with a plate in front of them, including holding } \\
\text { a fork, cutting food and drinking from a glass }\end{array}$ & $\begin{array}{l}\text { Difficulty having a bath by themselves, including getting in and out of the } \\
\text { shower or bathtub }\end{array}$ \\
\hline $\begin{array}{l}\text { Difficulty in going to the bathroom alone including sitting down and } \\
\text { getting up from the toilet }\end{array}$ & Difficulty walking at home alone from room to room \\
\hline Difficulty to get dressed alone & Difficulty in getting into bed to lie down, or out of bed alone \\
\hline \multicolumn{2}{|l|}{ Difficulty in sitting down or getting up from a chair alone } \\
\hline \multicolumn{2}{|c|}{ Difficulties in performing Instrumental Activities of Daily Living } \\
\hline Has difficulty to buy groceries alone & Has difficulty to manage finances alone \\
\hline Has difficulty in taking medications alone & Has difficulty to go to the doctor alone \\
\hline Has difficulty to go out alone using transportation & Has difficulty to manage finances alone (to manage their own money) \\
\hline \multicolumn{2}{|c|}{ Chronic diseases } \\
\hline Presence of any chronic physical or mental illness & Work-related musculoskeletal disorder \\
\hline Diabetes & Arthritis \\
\hline Hypertension & Depression \\
\hline High Cholesterol & Chronic Obstructive Pulmonary Disease \\
\hline Stroke or brain hemorrhage & Cancer \\
\hline Chronic back pain & Chronic kidney problem \\
\hline \multicolumn{2}{|c|}{ Use of health services } \\
\hline Place they usually seek care when they are sick & Reason for seeking care \\
\hline Time since last medical appointment & Where they last sought healthcare \\
\hline $\begin{array}{l}\text { Have searched for a place, service, or health professional for health- } \\
\text { related care in the last two weeks }\end{array}$ & $\begin{array}{l}\text { Have used some integrative and complementary practice, i.e. treatment such } \\
\text { as acupuncture, homeopathy, medicinal plants and herbal medicine etc. }\end{array}$ \\
\hline $\begin{array}{l}\text { Usually attend the same place, same doctor or same health service } \\
\text { when they need health care }\end{array}$ & Have any prescription drugs at their last visit \\
\hline \multicolumn{2}{|c|}{ Hospitalizations and medical emergencies } \\
\hline Hospitalization in the last year & Time hospitalized \\
\hline Number of hospitalizations in the last year & Emergency care at home \\
\hline \multicolumn{2}{|l|}{ Reason for hospitalization } \\
\hline \multicolumn{2}{|c|}{ Lifestyle habits } \\
\hline Drink alcohol & Perform physical activity \\
\hline Consume tobacco & \\
\hline
\end{tabular}

Fold refers to the explanatory capacity of the variable in percentage exposed in the results. From this test, it is possible to recognize independent variables strongly related to the dependent variable and with little relation to each other, excluding confounding possibilities. This therefore enables validating the authentic and accurate relationships between the independent variables and the outcome variable, with better accuracy than other tests frequently used in the literature ${ }^{(14)}$. Cross-validation allows you to section data into subsets, called folds, to use a knowledge-inducing algorithm. Each fold will be used as a test set once. The outcome enables calculation through the average of results obtained in the preceding steps ${ }^{(13)}$. 
Moving forward, only the variables that showed great competence to elucidate the outcome variable were evaluated, eliminating non-legitimate connections with the independent variables. The employability of this methodology allows us to uncover potentially useful, highly reliable and previously unknown aspects ${ }^{(13)}$.

Finally, the independent variables related to the dependent variable were evaluated using logistic regression to determine the scope of the associations. Logistic regression makes it possible to understand the chances for the occurrence of a given question, starting from a binary dependent variable and a grouping of independent predictive variables ${ }^{(15)}$. The formed model had an explanatory capacity of $65.5 \%$.

All analyzes were performed using WEKA software program, chosen for the present study due to its free availability, efficacy, agility and credibility ${ }^{(14,16)}$.

\section{ETHICAL ASPECTS}

The PNS-2013 was approved by the National Commission of Ethics in Research for Human Beings of the Ministry of Health under the opinion number 328.159, of June 26, 2013, respecting the Resolution 466/12 of the National Health Council ${ }^{(11)}$. Thus, the use of data generated by the PNS-2013 does not require further approval by ethics committees. It is noteworthy that the Ministry of Health encourages these data to be widely used in the most diverse ways and using different analysis approaches, as was done in the study under analysis, in order to subsidize and considerably expand the knowledge about the health characteristics of the Brazilian population.

\section{RESULTS}

The descriptive analysis showed that $64 \%(n=12,467)$ of the investigated older adults needed up to four medical appointments and $36 \%(\mathrm{n}=7,036)$ had five or more appointments, considering the 12 months preceding the survey.

Of the 57 variables considered for analysis, six were strongly related to the frequency of medical appointments over a period of up to 12 months, namely: gender; self-perception of general health condition; inability to perform any usual activities for health reasons; diagnosis of chronic disease; seeking a place, service or health professional for health-related care in the last two weeks and; hospitalization in the last year. All variables presented a percentage of 100 in the 10-fold cross-validation method which enables measuring the link between the independent and dependent variables.

Table 1 highlights the descriptive analysis of the independent variables that were related to the annual frequency of medical appointments among Brazilian older adults, while Table 2 shows the odds ratios of older adults needing too many annual medical appointments, according to the independent variables.

Taking into consideration five or more medical appointments within a 12 -month period, women were at higher odds of using the service over men (Table 1). Most of the older adults had a negative perception of health and had some kind of chronic disease (Table 1), which is responsible for increasing the chances of the individual having consulted the health service four times a year by 1.95 and 1.63 times, respectively, compared to positive perception and absence of disease (Table 2). Also, most of the investigated older adults reported not being unable to perform any usual activities for health reasons, or having sought a service or health professional for health-related care in the last two weeks, and having been hospitalized (Table 1). However, when these physical limitations and search for services are present, the chances of the older adult to have a high frequency of medical consultations were 1.37, 2.54 and 2.45 times, respectively (Table 2 ).

Table 1 - Descriptive analysis of independent variables related to the frequency of annual medical consultation in Brazilian older adults - PNS, Brazil, 2013.

\begin{tabular}{|c|c|c|c|c|c|c|}
\hline \multirow{3}{*}{ Independent variable and classes } & \multicolumn{2}{|c|}{ Up to 04 consultations } & \multicolumn{2}{|c|}{05 or more consultations } & \multicolumn{2}{|c|}{ Total } \\
\hline & $\mathrm{N}$ & $\%$ & $\mathbf{N}$ & $\%$ & $\mathbf{N}$ & $\%$ \\
\hline & 12467 & & 7036 & & 19503 & 100 \\
\hline \multicolumn{7}{|l|}{ Gender } \\
\hline Male & 5431 & 68 & 2515 & 32 & 7946 & 41 \\
\hline Female & 7036 & 61 & 4521 & 39 & 11557 & 59 \\
\hline \multicolumn{7}{|c|}{ Self-perception of general health condition } \\
\hline Positive & 5958 & 75 & 1944 & 25 & 7902 & 41 \\
\hline Negative & 6509 & 56 & 5092 & 44 & 11601 & 59 \\
\hline \multicolumn{7}{|c|}{ Has a doctor diagnosed them with any chronic, physical or mental illness, or long-term illness (over six months) } \\
\hline No & 4489 & 58 & 3243 & 42 & 7732 & 40 \\
\hline Yes & 7978 & 68 & 3793 & 32 & 11771 & 60 \\
\hline \multicolumn{7}{|c|}{ Unable to perform any of their usual health activities in the last two weeks } \\
\hline No & 1073 & 16 & 5594 & 84 & 6667 & 34 \\
\hline Yes & 11394 & 84 & 1442 & 11 & 12836 & 66 \\
\hline \multicolumn{7}{|c|}{ Have searched for a place, service, or health care for health-related care in the last two weeks } \\
\hline No & 9989 & 72 & 3974 & 28 & 13963 & 72 \\
\hline Yes & 2478 & 45 & 3062 & 55 & 5540 & 28 \\
\hline \multicolumn{7}{|l|}{ Hospitalization in the last 12 months } \\
\hline No & 11511 & 67 & 5615 & 33 & 17126 & 88 \\
\hline Yes & 956 & 40 & 1421 & 60 & 2377 & 12 \\
\hline
\end{tabular}


Table 2 - Odds ratios of increased medical appointment frequency (more than 4 appointments) in older adults according to independent variables - PNS, Brazil, 2013

\begin{tabular}{lc}
\hline Variable & Odds Ratio (OR) \\
\hline Gender & 1.00 \\
Male & 1.35 \\
Female & 1.00 \\
\hline Self-perception of general health condition & 1.95 \\
Positive & \\
Negative & 1.00 \\
\hline Has a doctor diagnosed them with any chronic, physical or mental \\
illness, or long-term illness (over six months) \\
No & 1.63 \\
Yes & 1.00 \\
\hline Unable to perform any of their usual health activities in the last two weeks \\
No & 1.37 \\
Yes & \\
\hline Have they attended a place, service, or health care provider for \\
health-related care in the last two weeks \\
No & 1.00 \\
Yes & 2.54 \\
\hline Hospitalization in the last 12 months & \\
No &
\end{tabular}

\section{DISCUSSION}

The search by individuals for health services has a multicausal origin, with the influence of biopsychosocial aspects ${ }^{(5)}$. The use of these services and the coverage achieved reflect their availability and additionally enable identifying the health needs of the population ${ }^{(17)}$, guiding future directions. Considering older adults, the use of health services by this population group focuses on the demands related to geriatric syndromes and frailty. Aging with health is not opposed to the absence of disease, and being an older adult without disease is a possibility, with it being necessary and essential for the population to understand that such conditions, well-being and functionality complement each other ${ }^{(18)}$.

As emphasized, the increase in the older adult population has increased the demand on health services ${ }^{(2)}$, including the investigated modality (frequency of medical appointments). The results reinforce the influence of previously mentioned aspects in the literature, and emphasize the interference of self-perception regarding the general health condition through the use of consultations with a medical professional.

Corroborating previous studies, the findings showed that female individuals aged 60 years or older had more frequent medical appointments $(\mathrm{OR}=1.35)^{(6,19)}$ when compared to males. It is known that men usually seek care late, usually when the disease is already installed ${ }^{(20)}$, reducing the number of years they live ${ }^{(21)}$. On the other hand, women commonly use lifelong health services more often for reasons related to their own gender, and perceive conditions with potential health risk earlier. Still, health services traditionally have numerous actions aimed at this gender, contributing to increase life expectancy and predominance of females among this population ${ }^{(21)}$.

Self-reporting the general health condition as negative emerges among the contributing factors for the increased chances of the older adults seeking medical consultations too frequently $(\mathrm{OR}=1.95)$, corroborating what was exposed in a previous study ${ }^{(9)}$. Health perception has a multidimensional character, is influenced by biopsychosocial issues and tends to be high over the years ${ }^{(22)}$. Some events directly interfere with health perception, such as the presence of chronic diseases and functional disability, being closely linked to the risk of complications and the continuous use of medicines, in turn increasing the demand and use of health services and medical consultations, respectively ${ }^{(22)}$. This aspect deserves special attention, since a poor perception of health is directly related to the increase in the number of hospitalizations, functional decline and dependence among older adults ${ }^{(23-24)}$. Identifying the health perception of older adults enables planning and executing actions focused on the uniqueness of the individuals and their real demands, motivating their care and adherence, thereby supporting better health conditions, maintenance of functional capacities and quality of life $\mathrm{e}^{(24)}$.

The medical diagnosis of any chronic physical or mental illness (over six months) increased the chances of older adults seeking medical consultations too frequently (OR $=1.63$ ) when compared to individuals who did not have such condition. It is understood that the presence of chronic diseases can aggravate the health condition and intensify the use of health services ${ }^{(9)}$. The negative repercussions resulting from the onset of chronic diseases fully affect the individual, and intensify when the appropriate follow-up is not performed ${ }^{(8)}$.

Similarly, older adults who reported that they were unable to perform any habitual activity for any health reason considering the two weeks prior to data collection were related to more frequent medical appointments $(\mathrm{OR}=1.37)$. It is understood that individuals with such restrictions often have poor health conditions. The presence of functional disability is commonly associated with comorbidities, making the demand for differentiated health care more frequent, in turn requiring actions of greater cost and complexity ${ }^{(8)}$. These conditions tend to evolve progressively, aggravating the limitations for Basic Daily Life Activities (BADL) ${ }^{(25)}$, increasing the incidence of hospitalizations and requiring routine medical consultations ${ }^{(2)}$.

The need to seek some kind of service or health professional for health-related care considering the two weeks preceding the PNS-2013 data collection was identified as a factor which most contributed to the increased probability of having more than four medical appointments within 12 months $(\mathrm{OR}=2.54)$. The reason for consultations with a medical professional was not considered, nor the periodicity of these consultations. In this sense, it is known that routine follow-up focusing on the maintenance of capacities and health conditions are predictors for successful aging. However, when these actions focusing on promotion and prevention are ineffective at the various healthcare levels, they lead to increased demand for health care ${ }^{(2)}$, expressing inefficiency of services and inequality in supply ${ }^{(26)}$.

Among the older adult participants of the PNS-2013, those who required hospitalization in the 12 months prior to the survey (for a period equal to or greater than 24 hours) 
had a higher number of medical appointments $(\mathrm{OR}=2.45)$ when compared to those who did not demand the use of such a service. Older people are more susceptible to hospitalization episodes, regardless of the associated conditions ${ }^{(27)}$, cases which usually require care and hospital stay are considered more severe, and require additional care ${ }^{(21)}$. In addition, the hospitalization period may culminate in the deterioration of the functional condition of older adults, resulting in greater dependence on returning to the family nucleus, and consequently greater follow-up with health professionals ${ }^{(28-29)}$.

It is known that negative consequences of clinical conditions of older adults which often require hospitalizations can be avoided through effective actions at the primary care level focused on health promotion, early diagnosis, prevention and appropriate treatment ${ }^{(2)}$. It is essential to emphasize the importance of promoting quality, resolute actions aimed at health promotion and damage prevention at all levels of care ${ }^{(2,9)}$. The use of preventive health services is constantly decreasing, as acute demands with a curative focus prevail when considering the reason which leading to the search $^{(7,9)}$. Therefore, it is up to managers and professionals to seek solutions respecting the singularities of the areas in which they operate. The benefits of the proper functioning of health services substantially contribute to improvements in the living conditions of the population ${ }^{(9)}$.

In summary, medical consultation positively contributes to healthcare when used in a timely manner, however, the excessive use of this modality available in health services becomes a signal of low resolution care, and generates disorganization of flows, in addition to directly interfering in other areas such as the economic area ${ }^{(30)}$. The losses extend to other areas and make it difficult for other users to access the health services ${ }^{(2)}$.
Still, the findings of this study should be carefully analyzed, since the sampling of older adults from the PNS2013 was used in full for the study, and did not consider possible limitations in the health of the older adults, while individuals who did not respond to the conformational question of the dependent variable were also excluded from the sample. Moreover, divergences between gender and region of residence of individuals were not analyzed separately. The implemented study conduct does not detract from the results of the study, and the influence of aspects which interfere in the search for consultations with medical professionals for the general layer of Brazilian older adults is evaluated, constituting a basis for future studies with specific delimitations.

Regarding the software used for the analysis, it considers the default values of $95 \%$ confidence interval and $p<0.05$, but does not present them individually for each variable added in the model. This is because any probability of influence on the confidence interval from the sample size is extinguished in the steps prior to the regression analysis, with the class balance and the dimensionality reduction test ${ }^{(14)}$.

\section{CONCLUSION}

The findings of this study reinforce the influence of multiple aspects which interfere in seeking consultations with medical professionals by Brazilian older adults. The results are associated with functional decline, the presence of chronic diseases, comorbidities and their consequences such as hospitalization, seeking health services or professionals, and negative health perception. Therefore, the importance of expanding and qualifying services at the three levels of care, especially primary care, is reinforced through effective prevention, protection and health promotion actions, thereby promoting better quality of life for Brazilian older adults.

\section{RESUMO}

Objetivo: Analisar os fatores associados à elevada frequência de consultas médicas (cinco ou mais consultas) entre idosos participantes da Pesquisa Nacional de Saúde - 2013. Método: Estudo transversal, quantitativo, realizado com os dados dos indivíduos com 60 ou mais anos $(\mathrm{n}=19.503)$. A variável desfecho sobreveio da pergunta: 'Quantas vezes consultou o médico nos últimos 12 meses? Foram elencadas 57 variáveis independentes. Utilizou-se o software Waikato Environment for Knowledge Analysis. Foi realizado o balanceamento do conjunto de dados, teste de redução de dimensionalidade, as variáveis que apresentaram-se fortemente relacionadas com a variável dependente foram analisadas por meio da regressão logística. Resultados: Das variáveis independentes elencadas apresentaram forte relação com a variável desfecho: sexo feminino, autopercepção negativa da condição de saúde, impossibilidade de realizar atividades habituais por motivo de saúde, diagnóstico de doença crônica, procura por serviço de saúde para atendimento relacionado à própria saúde, internação hospitalar. Conclusão: Os resultados refletem a relevância de ampliação e qualificação dos serviços, através de ações efetivas de prevenção, proteção e promoção da saúde.

\section{DESCRITORES}

Idoso; Saúde do Idoso; Indicadores de Serviços; Práticas Interdisciplinares; Serviços de Saúde; Enfermagem Geriátrica.

\section{RESUMEN}

Objetivo: Analizar los factores asociados con la elevada asistencia a consultas médicas (cinco o más consultas) entre personas mayores participantes en la Encuesta Nacional de Salud - 2013. Método: Estudio transversal, cuantitativo, llevado a cabo con los datos de los individuos de 60 o más años $(n=19.503)$. La variable resultado sobrevino de la pregunta: ‘Cuántas veces consultó usted con el médico los últimos 12 meses? Fueron enlistadas 57 variables independientes. Se utilizó el software Waikato Environment for Knowledge Analysis. Se llevó a cabo el balance del conjunto de datos, la prueba de reducción de dimensionalidad, las variables que se presentaron fuertemente relacionadas con la variable dependiente fueron analizadas mediante la regresión logística. Resultados: De las variables independientes enlistadas presentaron fuerte relación con la variable desenlace: sexo femenino, autopercepción negativa de la condición de salud, imposibilidad de realizar actividades habituales por motivo de salud, diagnóstico de enfermedad crónica, búsqueda por servicio sanitario para atención relacionada con la propia salud, estancia hospitalaria. Conclusión: Los resultados reflejan la relevancia de ampliación y calificación de los servicios, mediante acciones efectivas de prevención, protección y promoción de la salud.

\section{DESCRIPTORES}

Anciano; Salud del Anciano; Indicadores de Servicios; Prácticas Interdisciplinarias; Servicios de Salud; Enfermería Geriátrica. 


\section{REFERENCES}

1. Barbosa BB, Almeida JM, Barbosa MR, Rossi-Barbosa LAR. Avaliação da capacidade funcional dos idosos e fatores associados à incapacidade. Ciênc Saúde Coletiva. 2014;19(8): 3317-25. DOI: http://dx.doi.org/10.1590/1413-81232014198.06322013

2. Silva AMM, Mambrini JVM, Peixoto SV, Malta DC, Lima-Costa MF. Use of health services by Brazilian older adults with and without functional limitation. Rev Saúde Pública. 2017;51(1 Supl):S5. DOI: http://dx.doi.org/10.1590/s1518-8787.2017051000243

3. Melo DS, Martins RD, Jesus RPFS, Samico IC, Santo ACGG. Assessment of the responsiveness of a public health service from the perspective of older adults. Rev Saúde Pública. 2017;51:62. DOI: http://dx.doi.org/10.1590/S1518-8787.2017051006854.

4. Destro JR, Boing AF, D'Orsi' E. Associated factors to medical consultations by elderly adults in southern Brazil: a population based study. Rev Bras Epidemiol. 2014;17(3):692-704. DOI: http://dx.doi.org/10.1590/1809-4503201400030010

5. Dellaroza MSG, Pimenta CAM, Lebrao ML, Duarte YA. Association of chronic pain with the use of health care services by older adults in Sao Paulo. Rev Saúde Pública. 2013;47(5):914-22. DOI: http://dx.doi.org/10.1590/S0034-8910.2013047004427

6. Pilger C, Menon MU, Mathias TAF. Health services use among elderly people living in the community. Rev Esc Enferm USP. 2013;47(1):21320. DOI: http://dx.doi.org/10.1590/S0080-62342013000100027

7. Levorato CD, Mello LM, Silva AS, Nunes AA. Fatores associados à procura por serviços de saúde numa perspectiva relacional de gênero. Ciênc Saúde Coletiva. 2014;19(4):1263-74. DOI: http://dx.doi.org/10.1590/1413-81232014194.01242013.

8. Nunes JD, Saes MO, Nunes BP, Siqueira FCV, Soares DC, Fassa MEG, et al. Functional disability indicators and associated factors in the elderly: a population-based study in Bagé, Rio Grande do Sul, Brazil. Epidemiol Serv Saude. 2017;26(2):295-304. DOI: http://dx.doi. org/10.5123/s1679-49742017000200007

9. Paskulin LMG, Valer DB, Vianna LAC. Utilização e acesso de idosos a serviços de atenção básica em Porto Alegre (RS, Brasil). Ciênc Saúde Coletiva. 2011;16(6):2935-44. DOI: http://dx.doi.org/10.1590/S1413-81232011000600031

10. Instituto Brasileiro de Geografia e Estatística. Pesquisa Nacional de Saúde 2013: percepção do estado de saúde, estilos de vida e doenças crônicas [Internet]. Brasília: IBGE; 2014 [citado 2018 ago. 22]. Disponível em: ftp://ftp.ibge.gov.br/PNS/2013/pns2013.pdf

11. Damacena GN, Szwarcwald CL, Malta DC, Souza Júnior PRBD, Vieira MLFP, Pereira CA, et al. The Development of the National Health Survey in Brazil, 2013. Epidemiol Serv Saúde. 2015;24(2):197-206. DOI: http://dx.doi.org/10.5123/S1679-49742015000200002

12. Brasil. Ministério da Saúde; Secretaria de Políticas de Saúde, Departamento de Atenção Básica. Parâmetros para programação das ações básicas de saúde [Internet] Brasília; 2001 [citado 2018 jul. 22]. Disponível em: https://www.paho.org/bra/index.php?option=com docman\&view=download\&category_slug=atencao-primaria-em-saude-944\&alias=556-parametros-para-programacao-das-acoes-basicassaude-6\&ltemid=965

13. Cabena P, Hadjinian P, Stadler R, Verhees J, Zanasi A. Discovering data mining: from concept to implementation. New York: Prentice Hall; 1998.

14. Frank E, Hall MA, Witten IH. Data mining: practical machine learning tools and techniques. San Francisco: Morgan Kaufmann; 2016.

15. Kleinbaum DG, Klein M. Logistic regression. New York: Springer; 2010.

16. Vianna RCXF, Moro CMCDB, Moysés SJ, Carvalho D, Nievola JC. Data mining and characteristics of infant mortality. Cad Saúde Pública 2010;26(3):535-42. DOI: http://dx.doi.org/10.1590/S0102-311X2010000300011

17. Bastos GAN, Harzheim E, Sousa Alde. Prevalência e fatores associados à consulta médica entre adultos de uma comunidade de baixa renda do Sul do Brasil. Epidemiol Serv Saúde. 2014;23 (3):409-20. DOI: http://dx.doi.org/10.5123/S1679-49742014000300004.

18. Curitiba. Secretaria de Estado da Saúde, Superintendência de Atenção à Saúde. Avaliação multidimensional do idoso [Internet]. Curitiba; 2017 [citado 2018 ago. 04]. Disponível em: http://www.saude.pr.gov.br/arquivos/File/Apostila_Idoso241017.pdf

19. Lima-Costa MF, Loyola Filho AI, Matos DL. Trends in health conditions and use of health services by the Brazilian elderly: a study based on the National Household Sample Survey (1998, 2003). Cad Saúde Pública. 2007;23(10):2467-78. DOI: http://dx.doi.org/10.1590/ S0102-311X2007001000021

20. Silva DV, Freitas YNL, Oliveira TC, Silva RL, Pegado CPC, Lima KC. Oral health conditions and activities of daily living in an elderly population in Brazil. Rev Bras Geriatr Gerontol. 2016;19(6):917-29. DOI: http://dx.doi.org/10.1590/1981-22562016019.160031

21. Silva SPCe, Menandro MCS. Social representations of health and care for elderly men and women. Saude Soc. 2014;23(2):626-40. DOI: http://dx.doi.org/10.1590/S0104-12902014000200022

22. Medeiros SM, Silva LSR, Carneiro JA, Ramos GCF, Babosa ATF, Caldeira AP. Factors associated with negative self-rated health among non-institutionalized elderly in Montes Claros, Brazil. Ciênc Saúde Coletiva. 2016;21(11):3377-86. DOI: http://dx.doi.org/10.1590/1413812320152111.18752015

23. Jerez-Roig J, Souza DLB, Andrade FLJP, Lima Filho BF, Medeiros RJ, Oliveira NPD, et al. Self-perceived health in institutionalized elderly. Ciênc Saúde Coletiva. 2016;21(11):3367-75. DOI: http://dx.doi.org/10.1590/1413-812320152111.15562015

24. Zanesco C, Bordin D, Dos Santos CB, Müller EV, Fadel CB. Factors determining the negative perception of the health of Brazilian elderly people. Rev Bras Geriatr Gerontol. 2018;21(3):293-303. DOI: http://dx.doi.org/10.1590/1981-22562018021.170210

25. Fialho CB, Lima-Costa MF, Giacomin KC, Loyola Filho Al. Capacidade funcional e uso de serviços de saúde por idosos da Região Metropolitana de Belo Horizonte, Minas Gerais, Brasil: um estudo de base populacional. Cad Saúde Pública. 2014;30(3):599-610. DOI: http://dx.doi.org/10.1590/0102-311X00090913.

26. Daniel LP, Gomes AP. Eficiência na oferta de serviços públicos de saúde nos municípios do estado de Mato Grosso. Reflexões Econ [Internet]. 2015 [citado 2018 set. 12];1(1):179-218. Disponível em: http://periodicos.uesc.br/index.php/reflexoeseconomicas/article/ download/828/780

27. Bordin D, Cabral LPA, Fadel CB, Santos CB, Gden CRB. Factors associated with the hospitalization of the elderly: a national study. Rev Bras Geriatr Gerontol. 2018;21(4):439-46. DOI: http://dx.doi.org/10.1590/1981-22562018021.180059 
28. Zaslavsky O, Zisberg A, Shadmi E. Impact of functional change before and during hospitalization on functional recovery 1 month following hospitalization. J Gerontol A Biol Sci Med Sci. 2015;70(3):381-86. DOI: http://dx.doi.org/10.1093/gerona/glu168

29. Calero-García MJ, Ortega AR, Navarro E, Calero MD. Relationship between hospitalization and functional and cognitive impairment in hospitalized older adults patients. Aging Ment Health. 2017;21(11):1164-70. DOI: http://dx.doi.org/10.1080/13607863.2016.1220917

30. Nassery N, Segal JB, Chang E, Bridges JFP. Systematic overuse of healthcare services: a conceptual model. Applied health economics and health policy. Appl Health Econ Health Policy. 2015;13(1):1-6. DOI: 10.1007/s40258-014-0126-5 